Jurnal Tabarru' : Islamic Banking and Finance

Volume 3 Nomor 1, Mei 2020

p-ISSN 2621-6833

e-ISSN 2621-7465

\title{
ANALISIS PEGADAIAN SYARIAH DI KOTA PEKANBARU
}

\author{
Hidayat \& Zulhelmy \\ Fakultas Ekonomi (FE), Universitas Islam Riau (UIR) \\ Email: hidayat@eco.uir.ac.id \& zulhelmy@eco.uir.ac.id
}

\begin{abstract}
ABSTRAK
Kehadiran lembaga keuangan syariah sebagai solusi praktis dari praktek ekonomi dan keuangan konvensional yang ribawi dan berkembang lama, di antaranya adalah Pegadaian Syariah. Secara praktis, pegadaian syariah juga sebagai solusi bagi masyarakat yang mengalami kendala finansial, yang tidak memiliki akses di perbankan. Berdasarkan fakta tersebut, tujuan penelitian ini, untuk: (1) Untuk mengetahui pelaksanaan gadai di Pegadaian Syariah di Kota Pekanbaru, (2) Untuk menganalisis kritis kesesuaian Prinsip Akad di dalam Islam terhadap akad pelaksanaan gadai di Pegadaian Syariah Kota Pekanbaru. Subjek dalam penelitian ini, semua pihak yang terlibat secara langsung dalam pelaksanaan akad gadai di Pegadaian Syariah Kota Pekanbaru yang berjumlah 57 orang. Metode analisis yang digunakan adalah analisis deskriptif kualitatif terhadap data-data yang telah dikumpulkan dari tiga aspek, yaitu akad perjanjian gadai, taksiran biaya yang ditetapkan, tempo waktu dan tebusan agunan yang dilakukan. Setelah dilakukan penelitian dan di analisis secara kritis dari praktek gadai di Pegadaian Syariah di Pekanbaru, dimana fakta dari Pegadaian Syariah dilihat dari tiga aspek yang bertentangan dengan prinsip akad di dalam Islam. Adanya Multi akad (double contract), yakni akad rahn dan ijarah dalam transaksi rahn (gadai). Adanya praktek ribawi pada aspek taksiran biaya, karena adanya tambahan utang dari pokok pinjaman yang diberikan, selanjutnya terjadinya praktek kezhaliman dan melakukan tindakan yang bukan haknya. Dengan demikian ditarik kesimpulan bahwa pelaksanaan gadai di Pegadaian Syariah Kota Pekanbaru hukumnya haram karena bertentangan dengan prinsip Muamalah Maliyah di dalam Islam.
\end{abstract}

Kata kunci: Akad, Rahn, Pegadaian Syariah.

\begin{abstract}
Islamic financial institutions, one of which is Islamic Pawnshop, are practical solutions of conventional economic and financial practices that contain usury and develop over a long period of time. Islamic pawnshop practically also acts as a solution for people who experience financial constraints and do not have banking access. Based on these facts, this study aimed to: (1) find out pawn practice at Islamic Pawnshop in Pekanbaru, and (2) conduct critical analysis on suitability of contract/agreement principle in Islam to the implementation of pawn agreement at Islamic Pawnshop in Pekanbaru. Subjects involved in this study were all parties who had direct involvement in implementation of pawn agreement at Islamic Pawnshop Pekanbaru, totaling 57 people. Data were analyzed using qualitative descriptive analysis towards data collected from three aspects including pawn agreement, estimated cost set, due period and collateral payment made. The results of the research and critical analysis showed that pawn practice at Islamic Pawnshop Pekanbaru was contrary to the principle of contract in Islam since there were double contracts, namely rahn and ijarah contracts. Furthermore, there was a practice of usury on estimated cost aspect for there was an addition of debt from loan principal. Additionally, there was a practice of taking actions other than their rights. Therefore, it can be concluded that pawn practice at Islamic Pawnshop in Pekanbaru is haram because it is contrary to Muamalah Maliyah principles in Islam.
\end{abstract}

Keywords: Contract, Rahn, Islamic Pawnshop. 


\section{PENDAHULUAN}

Secara praktis, masyarakat Indonesia sudah lama mengenal istilah pegadaian, baik melalui lembaga pegadaian, maupun secara alami dilakukan antara individu di lingkungan masyarakat. Secara alami istilah transaksi gadai dikenal dengan sebutan "pegang gadai".

Bagi masyarakat, akad/transaksi gadai merupakan solusi praktis dan taktis ketika menghadapi persoalan finansial dan tidak bankable. Secara historis, gadai sudah dikenalkan sejak masa kolonial Belanda, melalui VOC mendirikan Bank Van Leening pada tahun 1746, tahun 1811 Inggris mengambil alih dan membubarkan Van Leening dan mendirikan Usaha Pegadaian. Pada 1901 secara resmi Lembaga Pegadaian Negara pertama didirikan di Sukabumi Jawa Barat, dan akhirnya didirikan beberapa kantor cabang di berbagai Kota di seluruh Indonesia, termasuk di Kota Pekanbaru, Riau.

Awal beroperasi di masyarakat masih bersifat konvensional. Namun, seiring tumbuhnya semangat (ghirah) umat Islam untuk bertransaksi berdasarkan agamanya (agama Islam), di antaranya dibidang ekonomi berdasarkan prinsip-prinsip muamalah, maka muncul dorongan kuat untuk mendirikan lembaga keuangan yang berlandaskan Syariat Islam. Adanya dorongan tersebut disebabkan secara prinsip maupun praktis, gadai konvensional menerapkan prinsipprinsip yang bertentangan dengan syariah Islam. Hal mendasarkan yang menjadi sorotan, adanya unsur MaGhRib (Maisyir/spekulasi, Gharar, Riba, dan Bathil) dalam pelaksanaan gadai yang selama ini dikenal oleh masyarakat (Zuhdi, 2017).

\section{TINJAUAN PUSTAKA}

Untuk mengetahui pelaksanaan akad/transaksi gadai (rahn) di Pegadaian Syariah Kota Pekanbaru dapat dilihat dari tiga aspek yaitu akad/kesepakatan yang terjadi antara pihak pihak menggadaikan (rahin) dan pihak penerima gadai (murtahin), biaya taksiran yang ditetapkan, dan waktu jatuh tempo dalam akad/transaksi gadai (rahn) di Pegadaian Syariah Kota Pekanbaru.

\section{Legalitas Gadai Syariah}

Akad/transaksi gadai pada Pegadaian Syariah menggunakan akad rahn. Pelaksanaannya berdasarkan fatwa Dewan Syariah Nasional Majelis Ulama Indonesia, yakni DSN MUI Nomor 25/DSN-MUI/III/2002 tentang Rahn (gadai) yang disahkan pada tanggal 26 Juni 2002, dan Fatwa DSN MUI Nomor 26/DSN-MUI/III/2002 tentang Rahn Emas. Kedua fatwa tersebut menjadi landasan dan pedoman beroperasinya Pegadaian Syariah Kota Pekanbaru, sekaligus memberikan solusi finansial kepada masyarakat yang bankable. Secara prinsip, Pegadaian Syariah tidak beroperasi sebelum mendapatkan legalitas hukum dari DSN MUI. Keberadaan DSN MUI, sebagai lembaga independen, mengawasi kesesuaian antara pelaksanaan akad/transaksi di Lembaga Keuangan Syariah (LKS) di antaranya Pegadaian Syariah dengan fatwa yang telah dikeluarkan. Hal mendasar yang dipastikan bahwa pelaksanaannya harus terhindar dari prinsip MaGhRiB, yakni Maisyir/spekulasi, Gharar, Riba dan Bathil.

\section{Realitas Akad di Pegadaian Syariah Kota Pekanbaru}

Fakta akad/transaksi yang terjadi pada akad gadai/rahn di Pegadaian Syariah Kota Pekanbaru menggunakan akad rahn dan ijarah. Akad rahn disepakati antara lembaga dengan nasabah dalam transaksi utang piutang atau pinjam meminjam. Sementara akad ijarah terjadi dan disepakati ketika nasabah menitipkan jaminan (agunan) kepada Lembaga Pegadaian Syariah Kota Pekanbaru. 
Adanya dua jenis akad yang disepakati pada Pegadaian Syariah secara rinci tertulis dalam SBR (Surat Bukti Rahn). SBR disepakati, dan bukti kesepakatan diperkuat dengan adanya penandatangan yang dilakukan oleh kedua belah pihak. Kedua jenis akad disepakati secara bersamaan antara kedua pihak yang berakad/bertransaksi.

Ketika menitipkan agunan, Pegadaian Syariah menetapkan biaya kepada nasabah, meliputi biaya penjagaan, penggantian ketika jaminan (agunan) hilang, tempat penyimpanan, pengelolaan, dan asuransi. Jenis barang dapat dijadikan agunan, seperti agunan logam mulia, seperti emas perhiasan, emas batangan, dan berlian., agunan kendaraan bermotor, dan agunan barang-barang elektronik.

\section{Biaya Administrasi dan Taksiran Agunan}

Dalam pelaksanaan akad/transaksi gadai (rahn) antara nasabah dengan lembaga pegadaian, secara praktis adanya keuntungan (profit) yang diperoleh lembaga dari akad/transaksi yang dilakukan. Keuntungan (profit) diperoleh lembaga dari berbagai biaya yang ditetapkan dan telah disepakati oleh kedua belah pihak, yaitu biaya administrasi yang ditaksir berdasarkan besar pinjaman yang diterima nasabah, dan juga biaya penitipan jaminan/agunan berupa upah yang diterima oleh Pegadaian Syariah dari agunan yang telah dititipkan. Untuk mengetahui biaya administrasi di Pegadaian Syariah Kota Pekanbaru dapat dilihat pada tabel 1 di bawah ini :

Tabel 1. Biaya Administrasi

\begin{tabular}{ccc}
\hline No & Platform Pinjaman & Biaya Administrasi \\
\hline 1 & $20.000-150.000$ & 1.000 \\
\hline 2 & $151000-500.000$ & 5.000 \\
\hline 3 & $501.000-1.000 .000$ & 8.000 \\
\hline 4 & $1.005 .000-5.000 .000$ & 16.000 \\
\hline 5 & $5.010 .000-10.000 .000$ & 25.000 \\
\hline 6 & $10.050 .000-20.000 .000$ & 40.000 \\
\hline 7 & $20.100 .000-50.000 .000$ & 50.000 \\
\hline 8 & $50.100 .000-200.000 .000$ & 60.000 \\
\hline
\end{tabular}

Sumber: Kantor Pegadai Syariah Kota Pekanbaru (2019)

Pada Tabel 1 diatas terlihat jelas bahwa besarnya utang atau pinjaman yang diterima mempengaruhi besarnya biaya administrasi yang dibebankan kepada nasabah. Begitu juga dengan biaya penitipan agunan/jaminan yang diperoleh dari akad ijarah dalam transaksi gadai di Kota Pekanbaru. Untuk lebih mengetahui taksiran biaya penitipan agunan dapat dilihat pada tabel 2 di bawah ini : 
2020, Jurnal Tabarru' : Islamic Banking and Finance 3 (1) : 78 - 85

Tabel 2. Taksiran Biaya Penitipan Agunan Gadai

\begin{tabular}{cll}
\hline No & \multirow{2}{*}{ Jenis Agunan } & \multicolumn{1}{c}{$\begin{array}{c}\text { Perhitungan Taksiran Biaya } \\
\text { Agunan }\end{array}$} \\
\hline \multirow{2}{*}{1} & \multirow{2}{*}{ Emas, Berlian } & $\begin{array}{l}\text { Taksiran/Rp. } 10.000 \times \mathrm{Rp} .85 \mathrm{x} \\
\text { Jangka Waktu } / 10\end{array}$ \\
\hline \multirow{2}{*}{2} & \multirow{2}{*}{ Elektronik } & $\begin{array}{l}\text { Taksiran/Rp. } 10.000 \times \mathrm{Rp} .90 \mathrm{x} \\
\text { Jangka Waktu } / 10\end{array}$ \\
\hline \multirow{2}{*}{ Kendaraan Bermotor } & $\begin{array}{l}\text { Taksiran/Rp. } 10.000 \times \mathrm{Rp} .95 \mathrm{x} \\
\text { Jangka Waktu / } 10\end{array}$ \\
\hline
\end{tabular}

Sumber: Kantor Pegadai Syariah Kota Pekanbaru (2019)

Tarif ijarah dihitung dari nilai taksiran barang jaminan/marhun dan tarif ijarah dihitung dengan kelipatan 10 hari. Simulasi perhitungannya sebagai berikut :

- Nasabah memiliki barang jaminan berupa emas dengan nilai taksiran $\mathrm{Rp}$. 10.000 .000 .

- Pinjaman (marhun bih) maksimum yang dapat diperoleh nasabah tersebut adalah Rp. 9.000 .000 (90\% x taksiran)

- Besarnya ijarah yang dibebankan kepada nasabah per 10 hari adalah:

- Biaya Penitipan (akad ijarah) = $(10.000 .000 / 10.000) \quad x \quad$ Rp. 85 x $(10 / 10)$

- Biaya Penitipan $($ akad ijarah $)=$ Rp. 85.000 .

- Jika nasabah menggunakan Marhun Bih selama 25 hari, dan ijarah ditetapkan dengan kelipatan per 10 hari, maka besar ijarah agunan adalah Rp. 255.000 dari Rp. 85.000.- x 3 dibayarkan pada saat nasabah melunas atau memperpanjang Marhun Bih.

\section{Jatuh Tempo atau Waktu}

Pelunasan utang/pinjaman dalam akad gadai/rahn bisa dilakukan nasabah tanpa menunggu berakhirnya jatuh tempo waktu yang di tetapkan nasabah tanpa menunggu berakhirnya jatuh tempo waktu yang ditetapkan dan disepakati. Hanya saja, ketika nasabah melakukan pelunasan, dengan mengembalikan pokok pinjaman yang telah diterima, dan membayar biaya penitipan sesuai besar taksiran biaya penitipan dari jenis barang yang digunakan. Setelah pelunasan tersebut dilakukan, Pegadaian Syariah Kota Pekanbaru akan mengembalikan agunan/jaminan kepada nasabah.

Bagi nasabah yang mengalami kesulitan dalam melakukan pelunasan setelah jatuh tempo/waktu yang disepakati, maka agunan/jaminan akan dilelang untuk melunasi pokok utang/pinjaman yang telah diterima nasabah, biaya penyimpanan barang agunan/jaminan, dan biaya-biaya yang ditimbulkan dari penjualan (lelang) yang dilakukan oleh pihak Pegadaian Syariah. Apabila harga jual (lelang) barang jaminan (marhun) melebihi kewajiban nasabah (rahin) maka kelebihannya dikembalikan kepada nasabah (rahin). Jika kelebihan tersebut tidak diambil, akan diserahkan kepada Badan Amil Zakat (BAZ) atau Lembaga Amil Zakat (LAZ) yang terakreditasi. Sebaliknya, jika jumlah penjualan (lelang) barang ternyata tidak mencukupi pokok pinjaman (marhun bih) dan membayar jasa penyimpanan, maka kekurangannya tetap menjadi kewajiban nasabah (rahin) untuk membayarnya.

Meski demikian, sebelum penjualan (lelang) agunan/barang jaminan yang dititipkan, nasabah dapat menggunakan skim pelunasan, yaitu pelunasan sekaligus, atau dengan sistem cicilan/angsuran. Nasabah yang melunasi menggunakan skim cicilan selama empat bulan. Ketika dalam waktu empat bulan, nasabah belum melakukan pelunasan utang/pinjamannya, maka boleh 
mengajukan perpanjangan waktu pelunasan, sebelum berakhir masa jatuh tempo yang ditetapkan.

Di samping itu, sebelum menjual agunan (marhun) bagi nasabah yang belum melakukan pelunasan, pihak Pegadaian Syariah Kota Pekanbaru senantiasa mengedepankan prinsip kehatihatian. Pihak Pegadaian Syariah terlebih dahulu melakukan beberapa tindakan, sebagai berikut:

1. Peringatan secara lisan

2. Peringatan tertulis

Pendekatan secara persuasif, dengan cara mendatangi nasabah untuk bermusyawarah dalam mencari solusi dari masalah wanprestasi yang terjadi, yaitu: (1) Gadai ulang; (2) Penambahan plafon; (3) Mengangsur; (4) Menjual sendiri obyek jaminan; dan (5) Penjualan obyek jaminan dilakukan oleh pihak pegadaian dengan melalui proses lelang.

\section{METODE PENELITIAN}

Jenis penelitian ini bersifat deskriptif analitis, yaitu memaparkan, menggambarkan atau mengungkapkan data-data pelaksanaan gadai syariah di Pegadaian Syariah Kota Pekanbaru, sehingga ditarik kesimpulan dari fakta analisis yang ditemukan (Sunggono, 2003). Subjek dalam penelitian semua pihak yang terlibat dalam transaksi pelaksanaan gadai baik syariah, seperti pimpinan atau karyawan, dan nasabah atau masyarakat Kantor Pegadaian Konvensional dan Syariah di Pekanbaru, berjumlah 57 orang. Metode analisis yang digunakan adalah metode analisis deskriptif kualitatif.

\section{HASIL DAN PEMBAHASAN}

Setelah dilakukan pemaparan dari fakta pelaksanaan akad/transaksi gadai di Pegadaian Syariah Kota Pekanbaru, selanjutnya dilakukan analisis kritis dari varibel yang diteliti, sebagai berikut :

\section{Pelaksanaan Akad Rahn (Gadai) di Pegadaian Syariah Kota Pekanbaru}

Dari fakta akad rahn (gadai) yang terjadi dan disepakati antara nasabah dengan Pegadaian Kota Pekanbaru ditemukan adanya multi akad dalam akad/transaksi tersebut. Praktek multi akad dalam transaksi gadai (rahn) di Pegadaian Syariah Kota Pekanbaru berlandaskan pada Fatwa DSN MUI Nomor 25/DSN-MUI/III/2002 tentang Rahn (gadai) yang disahkan pada tanggal 26 Juni 2002, dan Fatwa DSN MUI Nomor 26/DSN-MUI/III/2002 tentang Rahn Emas.

Penggabungan dua akad atau lebih menjadi satu akad dalam pembahasan fiqih kontemporer, disebut al-'uqud almurakkabah (akad rangkap atau multi akad). Menurut penggagasnya, akad rangkap adalah kesepakatan dua pihak untuk melaksanakan suatu muamalah yang meliputi dua akad atau lebih, misalkan akad jual beli dengan ijarah, akad jual beli dengan hibah, dan lain sebagainya. Semua akibat hukum dari akad gabungan (multi akad), semua hak yang ditimbulkannya dianggap satu kesatuan yang tidak dapat dipisahkan, yang sama kedudukannya akibat hukum dari satu akad (Hammad, 2005)

Aplikasi multi akad pada Pegadaian Syariah Kota Pekanbaru yaitu akad rahn (gadai) dan akad ijarah (sewa menyewa atau upah mengupah). Akad rahn disepakati ketika nasabah menerima utang/pinjaman yang diberikan pihak Pegadaian Syariah. Sementara, akad ijarah terjadi dan disepakati ketika marhun (agunan) yang diserahkan nasabah kepada Pegadaian Syariah sebagai jaminan dari pinjaman/utang yang dilakukan.

Menurut penggagasnya, multi akad hukumnya mubah (boleh). Hal ini berdasarkan kaidah fiqih: al-Ashlu fi alMuamalat al-Ibahah (hukum asal 
muamalah adalah boleh). Maka, haditshadits yang mengharamkan dua jual beli dalam satu jual beli (bay'ataini $f i$ bay'atin), atau melarang dua akad dalam satu akad (Shafqataini fi shafqatin) dipahami hanya pengeculian dari hukum asalnya (Hasanuddin, 2009).

Meski demikian, jika ditelaah lebih lanjut praktek multi akad yang terjadi Pegadaian Syariah Kota Pekanbaru tidak sah secara syar'i, dengan beberapa alasan: Pertama, kaidah fiqih yang digunakan tidak tepat. Dengan mendalami asal usulnya, akan ditemukan bahwa kaidah yang digunakan itu merupakan kaidah cabang dari kaidah al-Ashlu fi alAsy-ya' al-Ibahah (hukum asal segala sesuatu adalah boleh). Padahal, nash-nash yang mendasari kaidah yang mendasari kaidah al-Ashlu fi al-Asy-ya' al-Ibahah (Misalkan QS al-Baqarah [2] ayat 29) berbicara tentang hukum benda (materi), bukan tentang hukum muamalah (perbuatan manusia).

Kedua, ada nash yang secara jelas dan tegas melarang multi akad. Ibn Mas'ud Radhiallahu 'anhu berkata: Nabi Shallahu 'alaihi wa Sallam melarang dua kesepakatan dalam satu kesepakatan (HR. Ahmad, al-Musnad/I/308). Menurut Imam Taqiyuddin An-Nabhani, hadits ini melarang adanya dua akad dalam satu akad (al-Syakhshiyah al-Islamiyah, II/308). Hadits ini bukan pengecualian, melainkan larangan menggabungkan akad secara mutlak, tanpa melihat akad-akad yang digabungkan bertentangan atau tidak. Hal ini bisa didasari pada kaidah ushul fiqih: al-Muthlaq Yajri 'ala Ithlaqihi maa lam Yarid Dalil Yadullu 'ala at-Taqyid (dalil mutlak tetap pada kemutlakannya, selama tidak ada dalil yang membatasi (Wahbah Zuhaili, 2006).

Memang sebagian Ulama telah membolehkan multi akad. Namun, ulama yang membolehkan pun telah mengharamkan penggabungan akad tabarru' yang bersifat non komersial (seperti qardh, rahn, dan semisalnya) dengan akad yang bersifat komersial (seperti jual beli, ijarah, dan semisalnya).

\section{Biaya admintrasi dan Taksiran Biaya Agunan (marhun)}

Dari fakta biaya yang dibebankan oleh Pegadaian Syariah Kota Pekanbaru kepada nasabah merupakan tindakan yang diharamkan di dalam Islam. Karena biaya administrasi dan taksiran biaya agunan (marhun) merupakan pengambilan manfaat atas pemberian utang piutang/pinjam meminjam. Meski di dalam fatwa DSN-MUI disebut sebagai ujrah (upah) atas jasa penitipan dari akad ijarah, namun hakikatnya biaya administrasi dan biaya agunan yang ditetapkan merupakan rekayasa hukum (hilah) untuk menutupi riba yang dilakukan, yaitu pengambilan manfaat dari pemberian utang piutang, baik berupa tambahan (ziyadah), hadiah, atau apapun bentuk manfaat lain yang diperoleh.

Berdasarkan nash pengambilan manfaat apapun dari utang piutang hukumnya haram. Rasulullah Shallallahu 'alaihi wa Sallam bersabda: "Setiap pinjaman yang menarik manfaat adalah salah satu bentuk riba." (HR. Baihaqi dalam Ma'rifah dari Fadhlah ibn Ubaid) (Taqiyuddin An-Nabhani, 2003). Harits Ibn Usamah meriwayatkan dari Ali Radhiallahu 'anhudengan lafaz: "Sesungguhnya Nabi Shallallahu 'alaihi wa Sallam melarang pinjaman yang menarik manfaat." Dalam riwayat yang lain disebutkan: "Setiap pinjaman yang menarik manfaat adalah riba."

Larangan mengambil tambahan dari utang piutang atau pinjaman juga berdasarkan ijma' yang telah terjadi bawa setiap pinjaman yang di dalamnya disyaratkan adanya tambahan adalah haram. Ibnu Mundzir berkata: "Mereka telah berijma' bahwa apabila pemberi pinjaman mensyaratkan adanya tambahan 
atau hadiah atas pinjaman, lalu dia memberi pinjaman berdasarkan itu, jika dia mengambil tambahan tersebut berdasarkan itu, maka itu adalah riba." (Taqiyuddin An-Nabhani, 2003)

Dengan demikian jelaslah bahwa setiap tambahan yang diperoleh dari akad rahn (gadai) di Pegadaian Syariah Kota Pekanbaru baik tambahan dari biaya administrasi atau fee dari akad ijarah atas penyimpanan, penitipan, biaya tempat dan sejenisnya, dihukumi riba dan haram dilakukan di dalam Islam (QS. AlBaqarah [2]; 275).

\section{Jatuh Tempo atau Waktu}

Dari aspek waktu atau tempo pelunasan pinjaman secara umum tidak ada masalah. Karena pihak Pegadaian Syariah Kota Pekanbaru pelunasan yang dilakukan oleh nasabah boleh dilakukan tanpa menunggu tibanya masa jatuh tempo pelunasan. Kondisi ini ketika nasabah yang berhutang memiliki kemampuan untuk melunasi pinjaman atau utangnya.

Berbeda kondisinya, ketika nasabah yang tidak mampu melunasi utang/pinjamannya, maka diberi kelapangan sampai memiliki kemampuan untuk melunasi utang/pinjamannya. Meski Pegadaian Syariah Kota Pekanbaru juga melakukan tahapan, memberikan kelapangan kepada nasabah, tetapi kelapangan itu hanya sebagai bentuk hilah (alasan hukum) sehingga bisa menjual agunan/barang jaminan yang diserahkan nasabah kepadanya. Karena tujuan utama yang ingin dilakukan adalah menjual agunan (marhun) yang telah dititipkan nasabah.

Meski secara hukum, agunan (marhun) boleh dijual untuk melunasi utang/pinjaman rahin (nasabah), tetapi yang berhak menyita dan memaksa hanyalah Negara, bukan lembaga finansial seperti Pegadaian Syariah, dan yang menjual adalah pemiliknya, bukan orang lain, termasuk Pegadaian Syariah. Keberadaan Negara bisa memaksa atau menyita orang yang berhutang tetapi tidak bisa melunasi, dan berpiutang bisa meminta hakim untuk menyita atau memaksa pemilikinya (nasabah) untuk menjual hartanya, sehingga utang/pinjamannya segera dilunasi.

Dari Ka'ab Ibn Malik, bahwa "Rasulullah Shallallahu 'alaihi wa Sallam pernah menyita harta Muadz Ibn Jabal, dan menjualnya untuk membayar utangnya." (HR. Al-Hakim) (Taqiyuddin An-Nabhani, 2003). Kondisi berbeda, ketika yang berhutang sengaja untuk tidak melunasi atau mengulur-ulur utangnya, maka tindakan demikian termasuk kezhaliman (HR. Bukhari dari Abu Hurairah). Dalam hadits yang diriwayatkan Imam Ahmad, orang yang sengaja mengulur pembayaran utang/pinjaman, atau bahkan tidak enggan dalam melunasinya, maka akan dikenakan ta'zir kepadannya (Zallum, 2004).

\section{KESIMPULAN}

Setelah dilakukan penelitian, diperoleh berbagai data yang dibutuhkan, selanjutnya dilakukan analisis kritis dari tiga aspek, sehingga ditarik kesimpulan bahwa Pelaksanaan Akad/Transaksi Gadai (Rahn) di Pegadaian Syariah Kota Pekanbaru bertentangan dengan prinsip muamalah di dalam Islam, dan hukumnya haram, sebagai berikut:

1. Terjadi multi akad (double contract), yaitu akad rahn dan akad ijarah.

2. Adanya riba dalam transaksi yang dilakukan. Hal ini ditemukan dari adanya tambahan biaya dari pokok utang atau pinjaman yang diterima nasabah dari Pegadaian Syariah.

3. Secara umum aspek waktu atau jatuh tempo pelunasan, terlihat adanya upaya yang dilakukan pihak Pegadaian Syariah melakukan beberapa tahap sebelum menjual (lelang) agunan 
(marhun) milik nasabah. Namun, itu hanya hilah (alasan hukum) sehingga Pegadaian Syariah bisa memaksa dan menyita agunan nasabah, selanjutnya agunan tersebut di jual (lelang). Padahal yang berhak menjual adalah yang berhutang selaku pemilik sah barang agunan, untuk melunasi utangnya. Negara boleh menyita dan memaksa yang berhutang untuk menjual hartanya, sehingga bisa melunasi utang/pinjamannya.

\section{DAFTAR PUSTAKA}

Fatwa DSN MUI Nomor 25/DSNMUI/III/2002 tentang Rahn (gadai).

Fatwa DSN MUI Nomor 26/DSNMUI/III/2002 tentang Rahn Emas.

Hammad, Nazih. 2005. al-Uqud alMurakkabah fi al-Figh al-Islamiy, Dar al-Qalam. Damaskus.

Hasanudin. 2009. Multi Akad Dalam Transaksi Syariah Kontemporer Pada Lembaga Keuangan Syariah di Indonesia. UIN Syahid. Jakarta.

Sunggono, Bambang. 2003. Metodologi Penelitian Hukum. PT Raja Grafindo Persada. Jakarta.

Taqiyuddin An-Nabhani. 2003. Syakhsiyyah, Jilid II. Dar alUmmah. Beirut.

Zallum, Abdul Qadim. 2004. al-Amwal fi al-Dawlah. Darul Ummah. Beirut.

Zuhaily, Wahbah. 2006. al, al-Fiqhul Islamy Wa Adillatuhu, Terjemahan. C.V. Pustaka Media Utama. Bandung.

Zuhdi, Muhammad Harfin. 2017. PrinsipPrinsip Akad dalam Transaksi Ekonomi Islam. Iqtishaduna,Vol. 8, No. 7, P. 78-115. 